\title{
HUBUNGAN KECERDASAN INTELEKTUAL (IQ) DAN KECERDASAN EMOSIONAL (EQ) DENGAN KETERAMPILAN BERMAIN DALAM CABANG OLAHRAGA BULU TANGKIS
}

\author{
Muhamad Fazari, Imas Damayanti, Nur Indri Rahayu \\ Program Studi Ilmu Keolahragaan \\ Departemen Pendidikan Kesehatan dan Rekreasi \\ Fakultas Pendidikan Olahraga dan Kesehatan \\ Universitas Pendidikan Indonesia, Jl. Dr. Setiabudhi No. 229 Bandung \\ Email : Muhamadfazari186@gmail.com
}

\begin{abstract}
Abstrak
Penelitian ini bertujuan untuk mengetahui gambaran kecerdasan intelektual (IQ) dan kecerdasan emosional (EQ) atlet UKM bulutangkis upi serta hubungan kecerdasan intelektual (IQ) dan kecerdasan emosional (EQ) terhadap keterampilan bermain dalam cabang olahraga bulutangkis. Metode penelitian yang digunakan adalah deskriptif korelasional. Sampel penelitian yang digunakan yaitu 8 orang atlet bulutangkis dari Unit Kegiatan Mahasiswa bulutangkis di Universitas Pendidikan Indonesia yang diambil menggunakan teknik Purposive Sampling. Instrumen yang digunakan adalah Tes Kecerdasan (Intelegensi) yaitu APM (Advanced Progressive Matrics). Tes kecerdasan emosional menggunakan instrumen angket dan instrumen untuk keterampilan bermain menggunakan Games Performance Assesment Instrumen (GPAI). Uji hipotesis statistik dilakukan menggunakan perangkat lunak IBM SPSS Statistics version 21. Hasil penelitian menunjukan gambaran hasil tes kecerdasan intelektual (IQ) atlet UKM bulutangkis UPI mayoritas di atas rata-rata, sedangkan gambaran hasil tes kecerdasan emosional (EQ) mayoritas sedang. Adapun hasil analisis statistik pearson korelasi pada kecerdasan intelektual (IQ) dan kecerdasan emosional (EQ) terhadap keterampilan bermain. Hasil analisis menunjukan tidak terdapat hubungan yang signifikan antara kecerdasan intelektual (IQ) dengan keterampilan bermain dalam cabang olahraga bulutangkis p $0.082>0,05$, dan tidak terdapat hubungan yang signifikan antara kecerdasan emosional (EQ) dengan keterampilan bermain dalam cabang olahraga bulutangkis $p 0,128>0,05$.
\end{abstract}

Kata kunci: Kecerdasan intelektual (IQ), Kecerdasan emosional (EQ), Keterampilan bermain, Olahraga bulutangkis.

\section{PENDAHULUAN}

Bulu tangkis atau badminton adalah suatu olahraga raket yang dimainkan oleh dua orang (untuk tunggal) atau dua pasangan (untuk ganda) yang saling berlawanan. Mirip dengan tenis, bulu tangkis bertujuan memukul bola permainan ("kok" atau "shuttlecock") melewati jaring agar jatuh di bidang permainan lawan yang sudah ditentukan dan berusaha mencegah lawan melakukan hal yang sama. Bulu tangkis merupakan cabang olahraga yang banyak digemari oleh masyarakat di dunia,termasuk di Indonesia. Olahraga bulu tangkis dapat dimainkan mulai dari anak-anak hingga orang dewasa dengan menggunakan raket dan shuttlecock dan bisa dimainkan di lapangan terbuka ataupun lapangan tertutup.

Menurut Scroeter dan Bauersfeld pencapaian prestasi dan keterampilan bermain dalam olahraga dipengaruhi oleh dua faktor 
yaitu faktor eksternal dan faktor internal. Faktor eksternal terdiri dari sarana prasarana dan peralatan olahraga dan sistem kompetisi. Faktor internal terdiri dari keadaan psikologis atlet, pemahaman taktik atau strategi, keterampilan teknik, kemampuan fisik dan keadaan konstitusi tubuh. Faktor-faktor tersebut sangat berpengaruh terhadap seorang atlet, karena pada dasarnya seorang atlet yang akan bertanding mempunyai persiapan dengan sebaik-baiknya dari segi fisik maupun segi mental. Dari beberapa faktor tersebut, faktor psikologi dapat berpengaruh langsung terhadap atlet, namun atlet juga dapat dipengaruhi oleh faktor-faktor lain di luar dirinya yang kemudian mempengaruhi kondisi psikologisnya. Diantara faktor psikologi yang mempengaruhinya adalah tingkat intelegensi dan emosional atau IQ (Intelligent Quotient) dan EQ (Emotional Quotinal).

Intelegensi atau kecerdasan merupakan faktor penting yang sering menentukan kemenangan dalam pertandingan olahraga. (Suranto, 2005), khususnya dalam cabangcabang tertentu seperti sepak bola, bulu tangkis ataupun cabang beladiri. Artinya dalam cabangcabang tersebut memerlukan kemampuan untuk berpikir secara cepat dan tepat, kemudian bertindak secara cepat untuk mengantisipasi lawannya. Oleh karena itu kondisi ini erat kaitannya dengan olahraga agar tetap bertambah dengan baik harus tetap memperoleh stimulus atau rangsangan untuk berfungsi, dengan cara atlet tersebut harus dibiasakan untuk menggunakan kemampuan inteleknya. Selain dipengaruhi IQ (Intelligence Qoutient), juga dipengaruhi oleh faktor psikologis lain yaitu EQ (Emotional Quotient). EQ (Emotional Quotient) merupakan kemampuan untuk memotivasi diri, mengendalikan perasaan dan dorongan hati menjaga agar stres tidak mematikan kemampuan berpikir, berempati dan mengaplikasikan kecerdasan emosi secara efektif. Kecerdasan emosional (Emotional Quotient) telah disetarakan dengan kecerdasan intelektual (Intelligence Qoutient) dalam menentukan tingkat keberhasilan. IQ
(Intelligence Qoutient) tidak berfungsi dengan baik tanpa penghayatan emosional seseorang. Kedua intelegensi tersebut saling melengkapi, sehingga dapat dikatakan kunci keberhasilan prestasi adalah kondisi optimumnya IQ (IntelligenceQoutient) dan EQ (Emotional Quotient) Optimasi keduanya merupakan kunci dalam pencapaian prestasi dalam olahraga.IQ (Intelligence Qoutient) dan EQ (Emotional Quotient) merupakan faktor psikologi yang termasuk dalam faktor internal seseorang. IQ (Intelligence Qoutient) dan EQ (Emotional Quotient) termasuk dalam input yang berperan penting dalam menentukan menang atau kalah atlet dalam bertanding. Dengan demikian, IQ (Intelligence Qoutient) dan EQ (Emotional Quotient) dapat menentukan baik atau buruknya keterampilan bermain seorang atlet. Dan pada saat bermain bulutangkis pemain tersebut apakah mampu untuk melakukan berfikir secara tepat ketika hendak mengembalikan shutllecock ke daerah lawanyang tidak bisa di kembalikan oleh lawan, dan ketika keadaan terdesak apakah pemain mampu untuk mengendalikan emosional ketika dalam keadaan genting atau tertinggal jauh oleh lawan.

\section{METODE}

Dalam sebuah penelitian perlu adanya suatu desain penelitian. "Desain penelitian adalah rencana atau rancangan yang dibuat oleh peneliti, sebagai ancar-ancar kegiatan, yang akan dilaksanakan" (Arikunto, 2006). Fokus dalam penelitian ini adalah Kontribusi Kecerdasan dan Emosional terhadap keterampilan bermain dalam cabang olaharaga bulu tangkis. Adapun desain penelitian yang peneliti gunakan dalam penelitian adalah Deskriptif kuantitatif yang dapat diartikan sebagai metode penelitian yang berlandaskan pada filsafat positivisme, digunakan untuk meneliti pada populasi atau sampel tertentu, analisis data bersifat kuantitatif karena data penelitian berupa angka-angka dan analisis menggunakan statistik. (Sugiyono, 2015). (Sugiyono, 2015) "variabel adalah konstruk 
(construct) atau sifat yang akan dipelajari".Lebih lanjut Sutrisno Hadi (Arikunto, 2006) menyatakan variabel adalah sebagai gejala yang bervariasi. Berdasarkan permasalahan yang ada, variabel yang terdapat dalam penelitian ini terdiri dari:

\section{Variabel Bebas / Independent (X)}

Variabel bebas adalah variabel yang mempengaruhi atau menjadi sebab perubahannya atau timbulnya variabel dependent(terikat). Variabel bebas dalam penelitian ini adalah Kecerdasan dan Emosional.

\section{Variabel Terikat / Dependent (Y)}

Variabel terikat adalah variabel yang dipengaruhi atau yang menjadi akibat, karena adanya variabel bebas.Variabel terikat dalam penelitian ini adalah keterampilan bermain dalam cabang olahraga bulu tangkis.

\section{A. Tes Kecerdasan (Intelegensi)}

Tes intelegensi digunakan untuk mengetahui tingkat intelegensi seseorang, dilakukan dengan cara sampel diberikan soalsoal untuk menyelesaikan dengan diberi waktu. Tes ini bertempat di University Center Staf Unit Pelaksana Teknis Lembaga Bimbingan dan Konseling UPI.Tes yang digunakan yaitu APM (Advanced Progressive Matrics). Dimana tes APM adalah salah satu tes non verbal yang digunakan untuk mengukur kemampuan dalam hal sistematis dan melihat hubungan-hubungan bagian gambar yang tersaji serta menggambarkan pola fikir yang sistematis yang penyajiannya dapat dilakukan secara klasikal dan individu.

\section{B. Tes Kecerdasan Emosional}

Tes yang digunakan untuk mengukur tingkat kecerdasan emosional yaitu dengan menggunakan instrumen angket dari thesis Erna Latifah (2015).Pembuatan instrumen diawali dengan pembuatan kisi-kisi sampai pada pengujian validitas dan reliabilitas instrumen. Instrument angket telah di validitaskan Berdasarkan hasil koefisien Alpha Cronbach yang diperoleh $(\alpha=0,896)$ dan mengacu pada titik tolak ukur, maka dapat disimpulkan bahwa instrumen kecerdasan emosional memiliki tingkat reliabilitas yang sangat tinggi.

\section{Tes Keterampilan}

Tes yang di gunakan untuk mengukur keterampilan bermain pada olahraga bulu tangkis yaitu dengan menggunakan Game Performance Assessment Instrument ( GPAI) (Oslin et al., 1998) yaitu mengukur "perilaku kinerja game yang menunjukkan pemahaman taktis,serta kemampuan pemain untuk memecahkan masalah taktis dengan memilih dan menerapkanketerampilan yang sesuai "

\section{HASIL DAN PEMBAHASAN}

Diskusi temuan ini menguraikan tentang perihal permasalahan dan penemuan yang muncul selama melakukan penelitian kontribusi kecerdasan intelektual (IQ) dan Kecerdasan emosional (EQ) terhadap keterampilan bermain dalam cabang olahraga bulutangkis, berikut ini beberapa penemuan yang dirumuskan peneliti adalah sebagai berikut:

1. Gambaran hasil penelitian yang telah dilakukan oleh peneliti tentang tes kecerdasan intelektual (IQ), dari 8 sample atlet UKM bulutangis UPI 3 orang dengan kategori Superior, 3 orang dengan kategori di atas rata-rata, dan 2 orang dengan kategori rata-rata.

Dengan kata lain kemampuan kecerdasan intelektual (IQ) atlet UKM bulutangkis UPI sudah baik. 6 dari 8 orang yang memiliki kemampuan kecerdasan Intelektual (IQ) di atas rata-rata.

2. Gambaran hasil penelitian yang telah dilakukan oleh peneliti tentang tes kecerdasan emosional (EQ), dari 8 sample atlet UKM bulutangkis UPI, 6 orang dengan kategori sedang, dan 2 orang dengan kategori kecerdasan emosional (EQ) yang 
Tinggi.

Dengan kata lain kemampuan kecerdasan emosional (EQ) atlet UKM bulutangkis UPI masih kurang baik karena dari 8 sample hanya 2 orang yang memiliki kecerdasan emosional (EQ) yang baik.

Mengapa demikian peneliti mencoba menelusuri mengapa kemampuan kecerdasan emosional (EQ) atlet UKM bulutangkis upi masih kurang.

a. Kurangnya latihan untuk kecerdasan emosional (EQ)

b. Kurangnya jam terbang pertandingan sehingga dari jam terbang latihan yang banyak,atlet dapat belajar dari pengalaman baik dari aspek psikis,mental dan emosional mereka.

3. Hasil pada penelitian ini adalah tidak terdapat hubungan yang signifikan antara kecerdasan intelektual (IQ) dan Kecerdasan emosional (EQ) terhadap Keterampilan bermain dalam cabang olahraga bulutangkis. Faktor tersebut dilihat dari hipotesis penelitian yang telah dilakukan Kecerdasan intelektual (IQ) yaitu 0,847>0,05, maka H0 diterima dan di dapat nilai signifikansi Kecerdasan Emosional (EQ) yaitu 0,763 > 0.05 . Jadi dapat disimpulkan bahwa "Tidak Terdapat hubungan yang signifikan antara Kecerdasan intelektual (IQ) dan Kecerdasan Emosional (EQ) terhadap Keterampilan bermain dalam cabang olahraga bulu tangkis. Hal ini di pengaruhi berbagai hal yakni kurangnya sample pada saat penelitian, dan atlet yang bermain hanya di UKM bulutangkis upi saja. bentuk latihan pada saat pelatihan UKM Bulutangkis UPI, kemudian faktor kebugaran masing-masing pemain, pengalaman dalam bertanding.
Hasil analisis data yang didapat dari pengolahan data, tidak sesuai dengan hipotesis yang telah diajukan oleh peneliti yaitu tidak terdapat hubungan yang signifikan antara kecerdasan intelektual (IQ) dan Kecerdasan emosional (EQ) terhadap keterampilan bermain dalam cabang olahraga bulutangkis. Namun selain kecerdasan intelektual (IQ) dan Kecerdasan emosional (EQ) banyak sekali komponen-komponen lain yang mempegaruhi keterampilan bermain dalam cabang olahraga bulutangkis.

\section{KESIMPULAN}

Berdasarkan hasil pengolahan dan analisis data yang telah diuraikan, dapat dijabarkan kesimpulan dari hasil penelitian yang dilakukan. Adapun simpulan yang diperoleh adalah sebagai berikut.

Gambaran dari hasil tes kecerdasan intelektual (IQ) sampel yang termasuk, kriteria, "rata-rata" terdapat 2 orang, kriteria "diatas rata-rata" terdapat 3 orang, kriteria "superior" terdapat 3 orang dan rata-rata nilai tes kecerdasan intelektual 114.50, kecerdasan intelektual (IQ) atlet UKM bulutangkis UPI memiliki kemampuan kecerdasan Intelektual (IQ) di atas rata-rata.

Gambaran Dari hasil tes kecerdasan emosional (EQ) diketahui kriteria "sedang" terdapat 6 orang, kriteria "tinggi" terdapat 2 orang, dan rata-rata nilai konsentrasi yaitu 92.38

Tidak Terdapat hubungan yang signifikan antara kecerdasan intelektual (IQ) dan kecerdasan Emosional (EQ) terhadap keterampilan bermain dalam cabang olahraga bulutangkis bahwa korelasi antara kecerdasan intelektual (IQ) menunjukan $\mathrm{R}$ square $-0,082$ dengan nilai signifikansi $0,847>0,05$.

\section{DAFTAR PUSTAKA}

Agus Salim, (2008). Buku pintar Bulu tangkis. Yogyakarta: Binamuda Cipta kreasi.

Arikunto, S. (2006).Prosedur Penelitian Suatu Pendekatan Praktik. Jakarta: Rineka Cipta. 
Amiruddin (2010) Pengukuran Keterampilan Dasar Bermain Bulu Tangkis Pada Mahasiswa Universitas Abulytama (Jurnal) Aceh : FKIP Universitas Abulyatama.

Daniel Memmert,Steve Harvey (2008) Journal of Teaching in Physical Education,

Erna Latifah (2015) "Hubungan antara kecerdasan intelektual, kecerdasan emosional, dan keterampilan teknik dengan prestasi pencak silat”. (Thesis). Bandung. Universitas Pendidikan Indonesia

Imanudin, I. (2014) “Bahan Ajar Ilmu Kepelatihan Olahraga”.Bandung. Universitas Pendidikan Indonesia

Subarjah, H (2014) Permainan Bulutangkis. Bandung: Universitas Pendidikan Indonesia.

Subarjah, H (2010) Jurnal: Hasil Belajar Keterampilan Bermain Bulutangkis Studi Eksperimen Pada Siswa Diklat Bulutangkis Fpok-Upi. Bandung: Universitas Pendidikan Indonesia.

Sugiyono. (2015). Metode Penelitian Kuantitatif dan Kualitatif dan $R \& D$. Bandung: Alfabeta.

Suherman, A \& Rahayu, N.I. (2016) "Modul Statistika Untuk Ilmu Keolahragaan”. Bandung: Ilmu Keolahragaan. Fakultas Pendidikan Olahraga dan Kesehatan. Universitas Pendidikan Indonesia

Minna Blomqvist (2001) journal Game Understanding and Game Performance in Badminton

Nurhasan \& Cholil, D.H. (2007). Modul Tes dan Pengukuran Keolahragaan. Bandung: Fakultas Pendidikan Olahraga dan Kesehatan, Universitas Pendidikan Indonesia.

Philip Carter (2009) TEST AND ASSESS YOUR BRAIN QUOTIENT "Discover your true intelligence withtests of aptitude, logic, memory, EQ,creative and lateral thinking”" (jurnal) London

Rahmat Hidayatuloh, (2013) “ Perbandingan pegangan raket (Upper Grips dan Lower Grips) terhadap kecepatan dan akurasi pada saat melakukan tekhnik over head backhand smash pada cabang olahraga bulu tangkis.( Skripsi) Bandung Universitas Pendidikan Indonesia. 